\title{
Isolation of an iridovirus from pike-perch Stizostedion lucioperca
}

\author{
Hannele Tapiovaara ${ }^{1, *}$, Niels-Jørgen Olesen ${ }^{2}$, Jere Lindén $^{3, * *}$, \\ Eija Rimaila-Pärnänen ${ }^{4}$, Carl-Henrik von Bonsdorff ${ }^{5}$
}

\author{
${ }^{1}$ National Veterinary and Food Research Institute, Department of Virology and Epidemiology, Unit of Virology, POB 368, \\ FIN-00231 Helsinki, Finland \\ ${ }^{2}$ Danish Veterinary Laboratory, Hangovej 2, DK-8200 Århus N, Denmark \\ ${ }^{3}$ National Veterinary and Food Research Institute, Regional Laboratory of Kuopio, POB 92, FIN-70701 Kuopio, Finland \\ ${ }^{4}$ National Veterinary and Food Research Institute, Department of Pathology and Field Extensions, POB 368. \\ FIN-00231 Helsinki, Finland \\ ${ }^{5}$ Department of Virology, Haartman Institute, POB 21, FIN-00014 Helsinki University, Finland
}

\begin{abstract}
We have isolated a large virus from pike-perch Stizostedion lucioperca fingerlings with no signs of disease. The biochemical, structural, and serological properties of this newly isolated virus suggest that it belongs to the family Iridoviridae. The virus multiplied and was cytopathogenic in several cultured fish cell lines. The virus has a DNA-containing genome and is assembled in the cytoplasm. When viewed in electron micrographs, the assembly sites showed a paracrystalline array of hexagonal nucleocapsids. The ultrastructure of the pike-perch virus resembled that of previously isolated fish iridoviruses. It is an enveloped icosahedral DNA virus. The diameter of the nucleocapsid in thin sections was $127 \pm 3 \mathrm{~nm}$; in negatively stained preparates the size of the enveloped virus varied from 147 to $187 \mathrm{~nm}$. In immunofluorescence the virus was stained by rabbit antisera against EHN (epizootic haematopoietic necrosis) virus, sheatfish iridovirus and cod iridovirus. The pathogenicity of the virus isolate was studied by inoculation into juvenile rainbow trout Oncorhyncus mykiss. Experimental infection under aquarium conditions suggested that the virus is apathogenic to rainbow trout. The infective virus could be recovered from the viscera of inoculated fish during the first week post-infection, after which the proportion of virus-positive fish declined over time. A small proportion of the fish still carried the virus $24 \mathrm{~d}$ post-inoculation.
\end{abstract}

KEY WORDS: Iridoviridae - Iridovirus - DNA virus - Pike-perch · Fish virus

\section{INTRODUCTION}

Iridoviruses are large DNA viruses that are known to cause disease in insects, molluscs, amphibians and fish. The family Iridoviridae comprises the genera Iridovirus, Chloriridovirus, Ranavirus and Lymphocystivirus, and an additional suggested genus of goldfish iridoviruses (Francki et al. 1991). The iridoviruses found in fish and amphibians are classified either in the Ranavirus (type virus FV 3), the Lymphocystivirus (type virus fish lymphocystis disease virus, LCDV) or the Goldfish virus group (Goldfish iridoviruses 1 and 2).

\footnotetext{
•E-mail: hannele.tapiovaara@eela.fi

- Present address: National Agency for Medicines, POB 55. FIN-00300, Helsinki, Finland
}

The most common fish iridoviruses cause mild infections. LCDV has a broad host range and a world-wide distribution causing papillomatous tumours on skin and fins (Wolf 1988). Examples of other iridoviruses are the viral erythrocytic necrosis virus (VENV) and white sturgeon Acipencer transmontanus iridovirus (Hedrick et al. 1990). An iridovirus etiology has been also suggested in the cod ulcus syndrome (Jensen et al. 1979) and in an incident of high mortality in turbot fry Scophthalmus maximus (Bloch \& Larsen 1993) in Denmark.

Recently, previously unknown iridoviruses have been isolated in different parts of the world in association with serious disease outbreaks of cultured fish. The epizootic haematopoietic necrosis virus (EHNV) was isolated in Australia in association with fatal disease outbreaks in redfin perch Perca fluviatilis (Lang- 
don et al. 1986, Langdon \& Humphrey 1987) and rainbow trout Oncorhyncus mykiss (Langdon et al. 1988). Iridoviruses causing high mortality in sheatfish Silurus glanis and catfish Ictalurus melas were discovered in Germany (Ahne et al. 1989) and in France (Pozet et al. 1992), respectively. A recent study from South Carolina, USA, describes the isolation of an iridovirus from a diseased wild population of large mouth bass (Plumb et al. 1996). In addition, pathogenic iridoviruses affecting several fish species have been isolated in Asia (Inouye et al. 1992, Miyata et al. 1997).

Comparisons among the fish iridoviruses isolated from redfin perch (EHNV; Langdon et al. 1986) and amphibian (ranavirus: FV3; Bohle iridovirus: BIV), as well as sheatfish and catfish iridoviruses, suggest that all belong to the genus Ranavirus. The ranaviruses were found to be distinct from the other piscine iridoviruses, namely LCDV and the goldfish iridoviruses, when these viruses were compared both at the DNA and protein level (Essani \& Granoff 1989, Hedrick et al. 1992, Hengstberger et al. 1993, Mao et al. 1997).

The pike-perch is an original inhabitant in Finnish lakes, but has been cultivated for restocking purposes since 1978. Spawners are captured from natural populations from special brood-fish lakes. Spawning occurs in anchored floating net cages; after spawning the females are replaced, and the males remain and fan water above the nest with their pectoral fins to keep the eggs clean until hatching occurs at a water temperature of $>18^{\circ} \mathrm{C}$. Hatching time is minimised by raising the temperature to near $22^{\circ} \mathrm{C}$ i thereafter 2 to $5 \mathrm{~d}$ are usually required until the fry swim horizontally and can be transferred to water ponds for the summer and restocked early in autumn. An iridovirus was isolated from a batch of apparently healthy pike-perch fingerlings (mean size $5 \mathrm{~cm}$ ) collected just before restocking.

\section{MATERIALS AND METHODS}

Cell culture and original isolation of the virus. The following cell lines were used: bluegill fry fibroblast (BF-2), rainbow trout gonad (RTG-2), fathead minnow epithelium (FHM), Epithelioma papulosum cyprini (EPC) and chinook salmon embryo fibroblast (CHSE). The growth medium used was Eagle's MEM supplemented with $10 \%$ foetal bovine serum, $1 \%$ glutamine, $100 \mathrm{IU} \mathrm{ml}^{-1}$ penicillin and $40 \mathrm{\mu g} \mathrm{ml}^{-1}$ streptomycin. The growth temperature was $20^{\circ} \mathrm{C}$. Cells used in infection experiments were routinely inoculated 24 to $48 \mathrm{~h}$ after trypsinization. After inoculation of virus the growth temperature was $15^{\circ} \mathrm{C}$. The cells were grown in either $80 \mathrm{~cm}^{2}$ tissue culture flasks or 24 -well dishes (Nunc $\mathrm{A} / \mathrm{S} ;$ Roskilde, Denmark). For titration of infective virus, 10 -fold dilutions of virus were inoculated into subconfluent BF-2 cells grown on 96-well dishes (Nunc); titrations were performed in triplicate.

The virus was isolated from a tissue homogenate of pike-perch fingerlings diluted 1:10 in cell culture medium. The suspension was precleared by low speed centrifugation and then used to inoculate BF-2 and EPC cells at 2 dilutions $\left(10^{-1}\right.$ and $\left.10^{-2}\right)$

Determination of the biophysical properties of the virus. The temperature sensitivity of the virus isolate was determined by treating the virus for $30 \mathrm{~min}$ at $50^{\circ} \mathrm{C}$, followed by titration on $\mathrm{BF}-2$ cells. The $\mathrm{pH}$ sensitivity was studied by lowering the $\mathrm{pH}$ of the virus suspension in Hank's balanced salt solution (Gibco BRL) to 2.9 with $0.1 \mathrm{M}$ citric acid. After $4 \mathrm{~h}$ in low $\mathrm{pH}$ at room temperature the virus was titrated in $\mathrm{BF}-2$ cells seeded in 96-well plates.

The effect of lipid solvents on infectivity of the virus was investigated by incubating $4 \mathrm{ml}$ of virus dilution in Hank's balanced salt solution with $1 \mathrm{ml}$ of diethyl ether for $1 \mathrm{~h}$ at room temperature. Thereafter the solution was incubated on ice overnight. Next day the diethyl ether was removed by evaporation at room temperature, and the virus solution was titrated on BF-2 cells after removing diethyl ether. When determining the temperature, $\mathrm{pH}$ or lipid-solvent sensitivity, a preparation of control-treated virus was titrated simultaneously. The amount of virus was determined as tissue culture infective dose (TCID) $50 \mathrm{ml}^{-1}$.

Determination of nucleic acid. The virus was titrated in growth medium containing iododeoxyuridine (IUDR; $50 \mathrm{~kg} \mathrm{ml}^{-1}$; Fluka AG, Switzerland). Two RNA viruses, the infectious pancreatic necrosis virus ( $I P N V_{A b}$ ) and the European lake trout rhabdovirus (Koski et al. 1992, Björklund et al. 1994) were treated simultaneously. The results were compared with titrations of the same virus preparations in normal growth medium lacking the nucleotide analogue.

Preparation of virus for negative staining in electron microscopy (EM). The virus was inoculated in $\mathrm{BF}-2$ cell cultures, and the growth medium and cells were collected when the cytopathic effect (CPE) was complete (cells detached from the bottom of the flask). The intracellular virus was released by freezing and thawing 3 times. Of this virus-containing medium, $30 \mathrm{ml}$ was precleared by low-speed centrifugation. Glutaraldehyde (Electron Microscopy Sciences, Washington, PA, USA) was added to attain a concentration of $0.05 \%$, and the virus-containing supernatant was centrifuged through a 30\% sucrose cushion in a Beckman L8-60M SW 41 rotor at $20000 \mathrm{rpm}$ for $60 \mathrm{~min}$ at $+4^{\circ} \mathrm{C}$. The virus pellet was dissolved in $50 \mu \mathrm{l}$ of $\mathrm{TN}$ buffer $(50 \mathrm{mM}$ Tris- $\mathrm{HCl}$, pH 7.5; $150 \mathrm{mM} \mathrm{NaCl}$ ), and samples were applied to carbon-reinforced, formvar-coated grids and stained negatively for $10 \mathrm{~s}$ with $1 \%$ aqueous uranyl acetate, pH 4.1. 
Preparation of thin sections for EM. EPC cells grown on $5 \mathrm{~cm}^{2}$ culture dishes (Nunc) were infected with the virus. Cells were collected on Days 1 to 4 postinfection by adding $0.7 \mathrm{ml} 2.5 \%$ glutaraldehyde in $0.1 \mathrm{M} \mathrm{Na}$-cacodylate $\mathrm{pH} 7.2$ on cells without overlay medium, followed by detaching the cell layer with a 'rubber policeman'. The cells were pelleted and fixed for 30 min at room temperature. The glutaraldehyde fixative was substituted with $0.2 \mathrm{M}$ sucrose in $0.1 \mathrm{M}$ Na-cacodylate buffer ( $\mathrm{pH} 7.2$ ), postfixation was performed with $1 \%$ osmium tetroxide for $1 \mathrm{~h}$ followed by staining en bloc with $1 \%$ aqueous uranyl acetate overnight. After dehydration in an ethanol series, the samples were embedded in Epon 812. Thin sections were cut with a Sorvall MT-6000 ultramicrotome and thin sections poststained with lead citrate. A Jeol CS-100 II electron microscope was used for both thinsectioned and negatively stained samples.

The size of the naked intracellular nucleocapsid in thin sections was estimated by measuring the diameter of 14 nucleocapsids, vertex to vertex dimension, and calculating the mean size and standard deviation of the diameter. The size on the enveloped virus after negative staining was estimated by measuring the mean diameter of 10 negatively stained virus particles, respectively.

Hoechst stain. EPC cells grown on cover glasses were infected with the virus isolate; uninfected cells served as negative controls. The cells were fixed on Days 0 to 3 postinfection $(25 \%$ acetic acid, $75 \%$ methanol). The fixed cells were stained with Bisbenzamid fluorochrome $\mathrm{H} 33258$ (Reiden De Haen AG), $0.05 \mu \mathrm{g} \mathrm{ml}^{-1}$ in phosphate-buffered saline (PBS)

Staining of cells for immunofluorescence. Coverglass cultures of FHM cells were inoculated with the virus strain at dilutions of $500^{-1}$ and $50^{-1}$, respectively. The incubation time was $24 \mathrm{~h}$ and temperature $15^{\circ} \mathrm{C}$. Coverglass cultures were rinsed, fixed in $80 \%$ acetone and stained for immunofluorescence as previously described (Jørgensen et al. 1989) using dilutions of rabbit serum in the first reagent layer and rhodamineconjugated swine antibodies to rabbit immunoglobulin (Dako, Copenhagen, Denmark) as the second reagent layer in dilution 1:100. Rabbit antisera against the following viruses were used: (1) sheatfish iridovirus (Ahne et al. 1989), (2) perch iridovirus (EHNV), Lake Nillahcootie (Langdon et al. 1986), (3) cod iridovirus (Jensen et al. 1979), (4) lake trout rhabdovirus (Björklund et al. 1994), (5) IPN virus strain Sp (Jørgensen \& Grauballe 1971). The antisera against sheatfish iridovirus (221A $\alpha 62.90)$ and EHNV $(221 \mathrm{~B} \alpha 13.91)$, respectively, were kindly provided by Dr P. de Kinkelin, INRA, France. Antiserum against cod iridovirus, lake trout rhabdovirus and IPN virus were produced at the Danish Veterinary Laboratory. The antiserum against cod iridovirus was produced in 1986 by immunization of 2 rabbits (K16 \& K18) with crude cod iridovirus grown in Eagle's MEM without serum, concentrated $30 \times$ by ultracentrifugation, and mixed with equal amounts of Freund's Incomplete Adjuvant. Each rabbit was given 6 injections subcutaneously at intervals of $2 \mathrm{wk}$. Due to background staining in the immunofluorescence, the cod iridovirus antiserum was absorbed in vivo before use

Preparation of virus for experimental infection. The virus was plaque-purified twice; for plaque purification BF-2 cells grown in 12-well dishes were infected with 10 -fold dilutions of the 4 th passage of the virus for $1 \mathrm{~h}$ at $15^{\circ} \mathrm{C}$ after which $1 \mathrm{ml}$ of $0.25 \%$ agarose (SeaPlaque GTG agarose; FMC BioProducts, Rockland, ME, USA) in growth medium was layered on the cells. Fresh BF-2 cells in $80 \mathrm{~cm}^{2}$ tissue culture flasks (Nunc) were infected with the plaque-purified virus, and the growth medium and cells were collected when the CPE was complete. The virus was released from cells by homogenising with a high speed mixing probe $(4 \times 5$ s) on ice. The virus was cleared by low-speed centrifugation and the supernatant was kept on ice for $4 \mathrm{~d}$ until used for inoculation of fish. (Whittington \& Reddacliff 1995). The preparation to be inoculated was titrated before and after inoculation. Preparations from non-infected BF-2 cell cultures were used for inoculation of control fish.

Infection of rainbow trout. Four 300 l tanks containing 40 rainbow trout were used in the experiment. The 1 -yr-old fish (average weight $40 \mathrm{~g}$ ) were obtained from a state fish farm (Saimaa Fisheries Research and Aquaculture) monitored for virological and bacteriological disease. They were acclimatised for $1 \mathrm{wk}$ before infection and during this period the viscera of 5 fish were collected for virological examination. The fish were tranquillized with benzocain for 2 min before infection. Altogether 80 rainbow trout in 2 tanks were injected intraperitoneally (i.p.) with $0.1 \mathrm{ml}$ of virus suspension containing $5 \times 10^{5} \mathrm{TCID}_{50} \mathrm{ml}^{-1}$. As a negative control, 40 fingerlings in 1 tank were infected i.p. with $0.1 \mathrm{ml}$ of medium from non-infected cell cultures. The 40 fish in the 4 th tank were infected by immersion for $30 \mathrm{~min}$ in a $20 \mathrm{l}$ aerated tank containing $2.5 \times 10^{3} \mathrm{TCID}_{50} \mathrm{ml}^{-1}$ of virus.

The well-being and motility of fish as well as the temperature of water were monitored twice daily. The temperature varied from 15.5 to $19.5^{\circ} \mathrm{C}$. The oxygen content was monitored every second day and varied from 6.4 to $8.4 \mathrm{mg}^{-1}$. Throughout the experiment the fish were maintained in static aerated water, one third of which was changed approximately every second day; all outflowing water was heated to $95^{\circ} \mathrm{C}$.

The fish from one tank of i.p.-infected fish were examined virologically during the course of infection. 
Seven i.p.-injected fish were killed on Days 2, 4, 9 and 16 , respectively, and tissue material (liver, spleen, kidney) was collected for individual virological examination. The liver, spleen, and kidney from each fish were pooled and homogenised with pestle and mortar. A $10 \%$ suspension was prepared in growth medium and pre-cleared by low speed centrifugation. The supernatant was inoculated in BF-2 cell cultures in $10^{-1}$ and $10^{-2}$ dilutions. All fish from 3 other tanks $(1$ control, 1 bath-infected, 1 i.p.-infected) were killed after $24 \mathrm{~d}$ and examined virologically. Tissue material (liver, spleen, kidney) from 5 fish were pooled into 1 sample and processed as above. The presence of virus in the water from each tank was analysed at the end of the experiment. A $1 \mathrm{ml}$ sample from each tank was taken with the help of a syringe, and the sample was filtered through a $0.45 \mu \mathrm{M}$ filter and inoculated as $10^{-1}$ dilution in BF-2 cell cultures. The inoculated cell cultures were examined daily. A sample was considered negative if no CPE was observed after 3 passages $(7 \mathrm{~d}$ between each passage) in BF-2 cells.

\section{RESULTS}

The iridovirus was isolated from pooled organ material of apparently healthy pike-perch fingerlings. The material was inoculated simultaneously onto BF-2 and EPC cells. CPE was first observed after 1 subcultivation in BF-2 cells. The virus generated small foci in the cell carpet with rounding of cells on the edges of the foci (Fig. 1a). When CPE was complete in 3 to $4 d$, many of the rounded cells contained an intracytoplasmic vacuole or vacuoles (Fig. 1b) and the cells began to detach from the bottom of the flask. The vacuoles contained DNA, which was detected by staining with Hoechst stain. In addition to the nuclei, smaller intracytoplasmic inclusion bodies could be detected in the virus-infected cells 2 to $3 \mathrm{~d}$ postinoculation (results not shown). The staining pattern suggested packaging of DNA-containing viruses in these intracytoplasmic assembly sites.

The pike-perch virus was cytopathogenic in all the fish cell lines examined (BF-2, EPC, FHM, RTG-2, CHSE). The BF-2 and RTG-2 cells, however, were found to be the most sensitive to infection; in both cell lines CPE was detected $48 \mathrm{~h}$ post-inoculation. Titration of the virus in a growth medium containing $50 \mu \mathrm{M}$ IUDR reduced the infectivity of the virus 1000 -fold, indicating that the viral genome consisted of DNA. The same concentration of IUDR had no effect on the replication of 2 RNA viruses (IPNV and the European lake trout rhabdovirus; Koski et al. 1992, Björklund et al. 1994) analysed simultaneously with the pike-perch virus.
Treatment of virus with diethyl ether reduced the titre of the virus from $10^{5.6}$ to $10^{25} \mathrm{TClD}_{50} \mathrm{ml}^{-1}$, suggesting that infectivity of the virus is largely dependent on the lipid envelope surrounding the nucleocapsid. The pike-perch virus was sensitive to both heat and low $\mathrm{pH}_{i}$ treatment of the virus for $30 \mathrm{~min}$ at $50^{\circ} \mathrm{C}$ abolished the infectivity of the virus in $\mathrm{BF}-2$ cells. Similarly, infectivity was lost by maintaining the virus at low $\mathrm{pH}$ (2.9) for $4 \mathrm{~h}$ at room temperature.

In thin sections, the intracellular virus was detected as individual particles or in intracytoplasmic assembly sites as paracrystalline arrays of icosahedral virus particles (Fig. 2a). The mean diameter of 14 intracellular nucleocapsids was $127 \mathrm{~nm}$ with a standard deviation of $3 \mathrm{~nm}$. The virus particles acquired an envelope by budding through plasma membranes (Fig. $2 \mathrm{~b}, \mathrm{c}$ ). The size of the negatively stained enveloped viruses varied between 147 and $187 \mathrm{~nm}$. The mean diameter of 10 particles was $167 \mathrm{~nm}$ with a standard deviation of $11 \mathrm{~nm}$ ). The structure of the newly forming envelope was 3-layered with an inner electron-dense layer surrounded by a lighter area. The lightly pre-fixed and negatively stained virus particles retained some features of hexagonal symmetry (Fig. 2d). A regular array of subunits was visible on the surface of the virus (Fig. 2e). Without pre-fixing the integrity of the virus particle was lost, such that it could be visualised as a fuzzy, snowball-like particle, sometimes surrounded by a unit membrane (results not shown).

The fluorescence pattern of the iridovirus-infected FHM cells stained with various rabbit antisera is given in Table 1. Positive staining was clearly observed using rabbit antisera against EHNV, sheatfish iridovirus and cod iridovirus, respectively (Fig. 3). Staining was mainly observed as cytoplasmatic inclusion bodies and small perinuclear granula. Cell membranes were only stained in a few cells. No staining was observed with rabbit antisera against IPNV and lake trout rhabdovirus, respectively.

The pathogenicity of the virus was examined by infecting rainbow trout $(10$ to $15 \mathrm{~cm}$ ) either by i.p. injection or immersion. For this, 80 fish in 2 separate tanks (40 fish $\operatorname{tank}^{-1}$ ) were infected by i.p. inoculation $(0.1 \mathrm{ml}$ of solution containing $5 \times 10^{5} \mathrm{TCID}_{50} \mathrm{ml}^{-1}$ ) and 40 fish by immersion in $2.5 \times 10^{3} \mathrm{TCID}_{50} \mathrm{ml}^{-1}$. There was no mortality in the control tank with non-infected fish, or in tanks infected either by i.p. injection or immersion.

No signs of disease or abnormal behaviour were detected during the 24 d. The i.p.-injected rainbow trout in one tank were examined virologically during the course of the experiment. Seven fish were killed on Days 2, 4, 9 and 16 after infection. The internal organs were inspected and collected for virological examination. No gross abnormalities in the internal organs of infected fish could be detected. Furthermore, no signs 


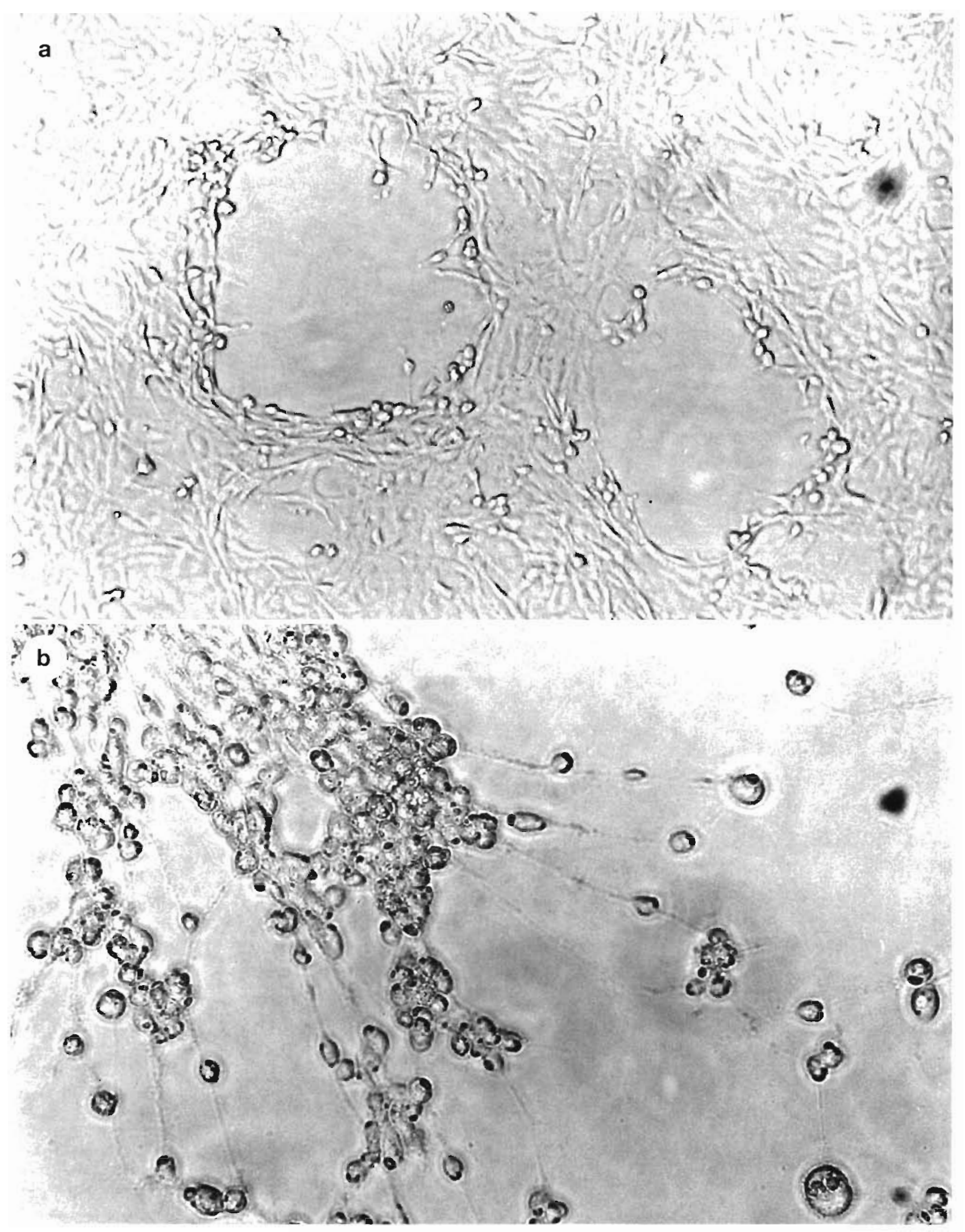

Fig. 1. BF-2 cells infected with the pike-perch virus. The CPE starts as discrete foci of infection with rounding of cells on the edges of the foci $(a ; \times 100)$. Later in the course of infection the virus is assembled in intracytoplasmic light reflecting vacuoles $\left(b_{;} \times 200\right)$ 

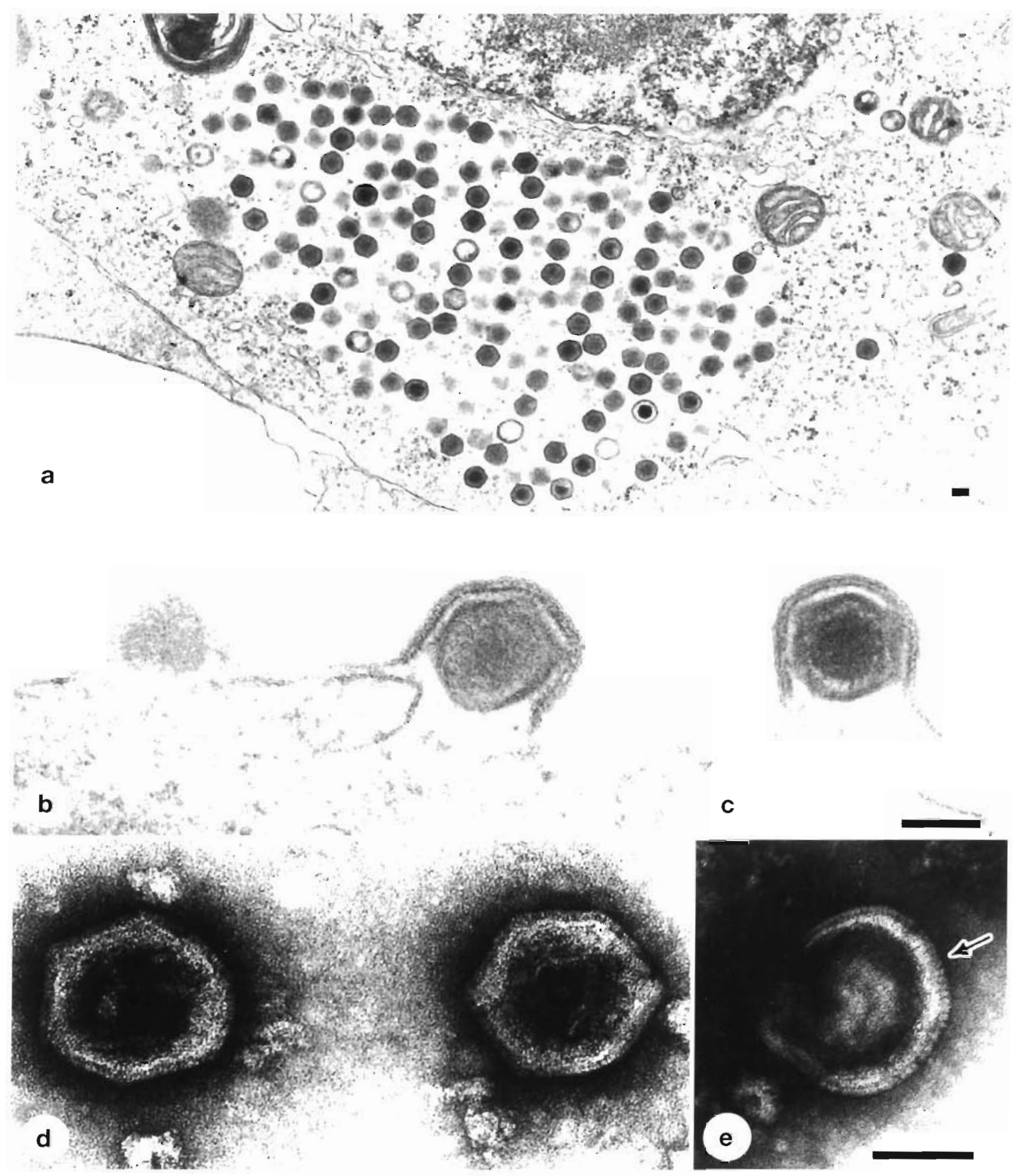

Fig. 2. EPC cells infected with the pike-perch virus, processed for EM as described in 'Materials and methods' (a-c) Thin sections of EPC cells infected with the pike-perch inidovirus. Viral nucleocapsids were mainly localised in intracytoplasmic assembly sites (a). The virus particles acquired the viral envelope by budding through plasma membrane $(b, c)$. (d, e) Negative staining of the pike-perch virus. Scale bars = $100 \mathrm{~nm}$. Bar tor both (b) and (c) is shown in (c); bar for both (d) and (e) is shown in (e). Arrow shows the regular array of subunits on the surface of the virus particle 
Table 1. Immunofluorescence results with pike-perch iridovirus, cod iridovirus, and 2 other fish viruses using homologous and heterologous antisera. Reactions: - , no reaction ${ }_{+}$, weak $_{i}++$, moderate,++ : strong; nd, not done

\begin{tabular}{|lcccc|}
\hline Antiserum & & \multicolumn{2}{c|}{ Virus } & \\
& Pike-perch iridovirus & Cod iridovirus & IPN virus & Lake trout rhabdovirus \\
\hline Rabbit anti cod iridovirus & ++ & +++ & nd & nd \\
Rabbit anti EHN virus & ++ & ++ & nd & nd \\
Rabbit anti sheatfish iridovirus & ++ & ++ & nd & nd \\
Rabbit anti IPN virus & - & - & +++ & - \\
Rabbit anti lake trout rhabdovirus & - & - & - & +++ \\
\hline
\end{tabular}

of disease or changes in the behaviour of fish were observed during the experiment, even though the virus could be recovered from the pooled internal organs (liver, spleen, kidney) of the infected fish. The iridovirus could be isolated from the viscera of all i.p.infected fish examined (14/14) on Days 2 and 4 after infection, indicating a successful infection. Towards the end of the experiment the proportion of viruspositive fish was reduced. On Day 9,3 out of 7 fish $(43 \%)$ were virus-positive. When the experiment was terminated after $24 \mathrm{~d}, 2$ out of 12 infected fish (17\%)

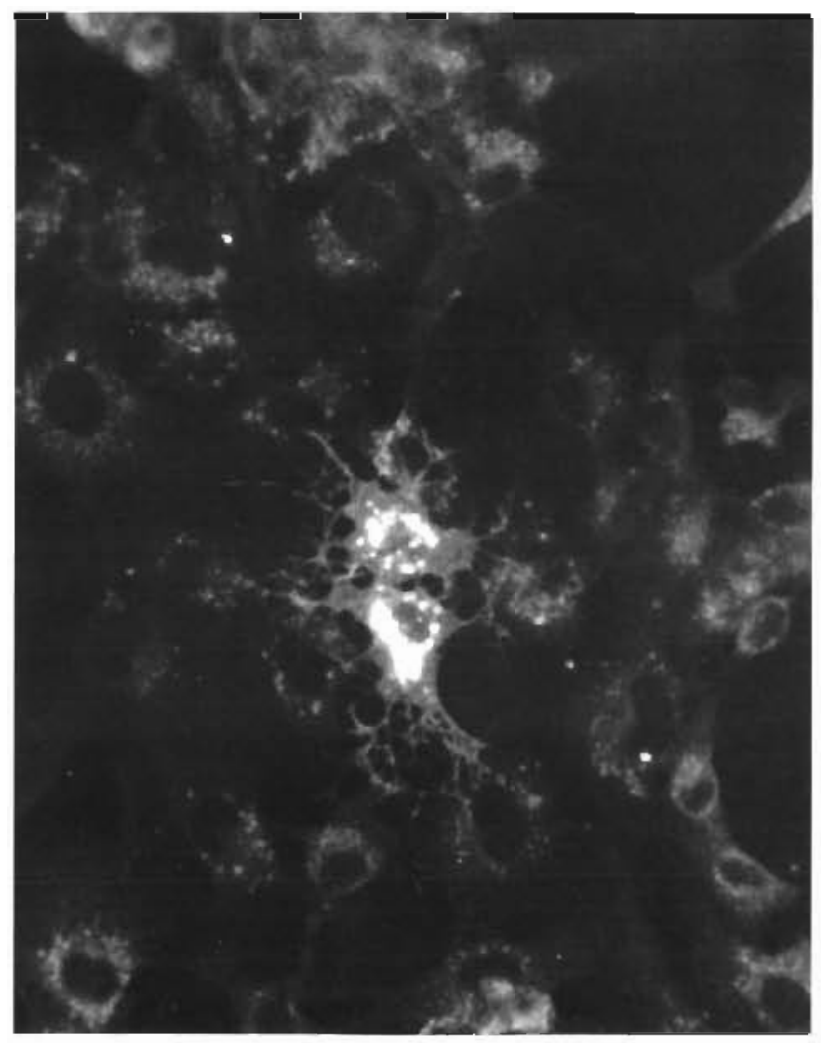

Fig. 3. Immunofluorescence micrograph showing the crossreaction staining of pike-perch iridovirus infected FHM cells with rabbit antiserum against sheatfish iridovirus as the primary antibody and rhodamine-conjugated swine antibody against rabbit IgG as the secondary antibody $(\times 400)$ still carried the virus. The unconcentrated tank water was found to be negative for infective virus at the end of the experiment.

No virus was isolated from samples taken before infection. All fish in the remaining 3 tanks 11 control, 1 bath-infected and 1 i.p.-infected, respectively) were killed on Day 24 after infection. All fish were examined virologically jn pools of 5 fish. Virus was re-isolated from 3 out of 8 pools of i.p.-infected fish. No virus could be isolated from fish infected by immersion or from the non-infected fish.

\section{DISCUSSION}

The immunofluorescence results in combination with the EM data indicate that the pike-perch virus should be classified in the Iridoviridae family. The large size, DNA genome, lipid-containing envelope and thermosensitivity are all properties typical of members of the Iridoviridae. Furthermore, we could detect DNAcontaining inclusion bodies typical of the Iridoviridae family in the cytoplasm of infected EPC cells. The infectivity of the virus was reduced by treatment with ether indicating that the lipid envelope enhanced infectivity of the virus. Fish iridoviruses isolated thus far belong either to the genera Lymphocystivirus or Ranavirus. This and the fact that members of the genera Iridovirus and Chloriridovirus are resistant to ether (Francki et al. 1991) indicate that the pike-perch virus is a member of either the Ranavirus or Lymphocystivirus genera.

The ultrastructure of this virus resembled that of the previously studied fish iridoviruses (Klump et al. 1983, Berthiaume et al. 1984, Heppell \& Berthiaume 1992) The ultrathin sections of the maturing virus showed an icosahedral particle surrounded by a 2 or 3 layered envelope. The negatively stained particles were surrounded by membrane with a regular array of subunits on the outer surface.

The growth properties and wide range of susceptible fish cell lines resemble those reported for EHNV and the iridovirus isolated from catfish (Langdon et al. 1986, Pozet et al. 1992, Hengstberger et al. 1993). 
The Australian and European iridoviruses share common epitopes as they cross-react serologically, making the use of polyclonal rabbit antisera unsuitable for differentiation of the viruses by immunofluorescence. The results of the present study indicate that the 2 iridoviruses from pike-perch and cod, respectively, fall into this serologically similar group of iridoviruses. Immunoblotting and PCR (polymerase chain reaction) of the major viral coat protein combined with sequencing of the obtained PCR product have been successfully used to differentiate between fish iridoviruses (Hengstberger et al. 1993, Mao et al. 1997) and this approach will be used in the future to further characterize the iridovirus isolated from pike-perch. However, there is a strong need for the development of quicker and specific diagnostic tools especially tor EHNV, but also for sheatfish iridovirus and other European pathogenic iridoviruses.

Apparently the present Finnish iridovirus isolate from pike-perch is not pathogenic for rainbow trout in these experimental conditions. Rainbow trout was chosen as the first fish species to be analyzed for susceptibility to the pike-perch iridovirus infection, because of the economical impact on the rainbow trout farming in Finland. Although the rainbow trout succumbs in natural infections caused by EHNV, it is known that it can be resistant to infection depending on experimental conditions. In our experiments we used conditions which would favour pathogenicity of EHNV for rainbow trout (Whittington \& Reddacliff 1995). However, it is possible that the conditions we chose were not optimal for the pathogenicity of the pike-perch iridovirus. A small fraction of the i.p.-injected fish were found to carry the iridovirus $24 \mathrm{~d}$ after infection, suggesting that a true carrier status for this virus could exist in fish. A carrier state of several weeks has been reported in rainbow trout experimentally infected with EHNV (Whittington $\&$ Reddacliff 1995). Therefore, our data on the pathogenicity of the pike-perch iridovirus for rainbow trout and for other fish species is still inconclusive. The cod iridovirus from Denmark has been reported to cause some mortality in cod (Jensen \& Larsen 1982).

The original isolations of this virus were from apparently healthy pike-perch from 2 separate locations in Finland during the summer 1995. It seems likely that pike-perch fingerlings originating from the first positive pond carried the iridovirus to the second location as the second owner had obtained his pike-perch fingerlings from the first owner.

The pike-perch iridovirus does not appear to be widespread in Finland since pike-perch fingerlings originating from several locations in Finland have been examined virologically for several years, and the virus has been detected only in 2 separate earth ponds. The source of this virus is unknown.
All our data suggest that the virus isolated from Finnish pike-perch is a member of the genus Ranavirus in the Iridoviridae family. Further comparison between the biochemical properties of EHNV, cod iridovirus and the pike-perch virus isolate is presently being undertaken.

Acknowledgements. We gratefully acknowledge Richard Whittington and Päivi Pylkko for their useful advice in the in vivo infection experiment. We also thank Lars Axel Lindberg for providing facility for preliminary EM visualisation of the virus isolate at the Department of Anatomy, Helsinki University Faculty of Veterinary Medicine. The skillful technical assistance of Anssi Mörttinen, Riitta Liimatainen, Leena Anttonen and Mette Lorentzen is greatly appreciated. We also thank the Finnish Game and Fish Research Institute for suppiyng the fish used in lite infection experiment. Dr P. Do Kinkelin, INRA, Jouy-en-Josas, France, is greatly acknowledged for supplying the rabbit antisera against EHNV and sheatfish iridovirus.

\section{LITERATURE CITED}

Ahne W, Schlotfeldt HJ, Thomsen I (1989) Fish viruses: isolation of an icosahedral cytoplasmic deoxyribovirus from sheatfish (Silurus glanis). J Vet Med B 36:333-336

Berthiaume L, Alain R, Rocin J (1984) Morphology and u]trastructure of lymphocystis disease virus, a fish iridovirus, grown in tissue culture. Virology 135:10-19

Björklund HV, Olesen NJ, Jørgensen PEV (1994) Biophysical and serological characterization of rhabdovirus $903 / 87$ isolated from European lake trout Salmo trutta lacustris. Dis Aquat Org 19:21-26

Bloch B, Larsen JL (1993) An iridovirus-like agent associated with systemic infection in cultured turbot Scophthalmus maximus fry in Denmark. Dis Aquat Org 15:235-240

Essani K, Granoff A (1989) Amphibian and piscine iridoviruses: a proposal for nomenclature and taxonomy based on molecular and biological aspects. Intervirology 30 : $187-193$

Francki RIB, Fauquet CM, Knudson DL, Brown F (eds) (1991) Classification and nomenclature of viruses. 5th Report of the International Committee of Taxonomy of Viruses. Arch Virol Suppl 2:132-136

Hedrick RP, Groff JM, McDowell TS, Wingfield WH (1990) An iridovirus infection of the integument of the white sturgeon Acipenser transmontanus. Dis Aquat Org 8:39-44

Hedrick RP, McDowell TS, Ahne W, Torhy C, de Kinkelin P (1992) Properties of three iridovirus-like agents associated with systemic infections of fish. Dis Aquat Org 13:203-209

Hengstberger SA, Hyatt AD, Speare R, Coupar BEH (1993) Comparison of epizootic haematopoietic necrosis and Bohle iridoviruses, recently isolated Australian iridoviruses. Dis Aquat Org 15:93-107

Heppell J, Berthiaume L (1992) Ultrastructure of lymphocystis disease virus (LDV) as compared to frog virus 3 (FV3) and chilo iridescent virus (CIV): effects of enzymatic digestions and detergent degradations. Arch Virol 125:215-226

Inouye $K$, Yamano $K$, Maeno $Y$, Nakajima $K$, Matsuoka $M$, Wada Y, Sorimachi M (1992) Iridovirus infection of cultured red sea bream. Pagrus major. Fish Pathol 27:19-27

Jensen NJ, Bloch B, Larsen JL (1979) The ulcus-syndrome in cod (Gadus morhua). 3. A preliminary virological report. Nord Veterinaermed 31:436-442 
Jensen NJ, Larsen JL (1982) The ulcus-syndrome in cod (Gadus morhua). IV. Transmission experiments with two viruses isolated from cod and Vibno anguillarum. Nord Veterinaermed 34:136-142

Jorgensen PEV, Grauballe PC (1971) Problems in serological typing of IPN virus. Acta Vet Scand 12:145-147

Jørgensen PEV, Olesen NJ, Ahne W, Lorenzen N (1989) SVCV and PFR viruses: serological examination of 22 strains indicates close relationship between the two rhabdoviruses. In: Ahne W, Kurstak E (eds) Viruses of lower vertebrates. Springer Verlag, Berlin, p 349-366

Klump H, Beamais J, Devauchell G (1983) Structural and thermodynamic investigation of the chilo iridescent virus. Arch Virol 75:269-276

Koski P, Hill B, Way K, Neuvonen E, Rintamäki P (1992) A rhabdovirus isolated from brown trout (Salmo trutta $\mathrm{m}$. lacustris [L]) with lesions in parenchymatous organs. Bull Eur Assoc Fish Pathol 12(5):177-180

Langdon LS, Humphrey JD (1987) Epizootic haematopoietic necrosis, a new viral disease in redfin perch, Perca fluviatilis L., in Australia. J Fish Dis 10:289-297

Langdon JS, Humphrey JD, Williams LM (1988) Outbreaks of an EHNV-like iridovirus in cultured rainbow trout, Salmo gairdneri, in Australia. J Fish Dis 11:93-96

Editorial responsibility: Jo-Ann Leong,

Corvallis, Oregon, USA
Langdon JS, Humphrey JD, Williams LM, Hyatt AD, Westbury HA (1986) First virus isolation from Australian fish: an iridovirus-like pathogen from redfin perch, Perca fluviatilis L. J Fish Dis 9:263-268

Mao J, Hedruck RP, Chinchar VG (1997) Molecular characterization, sequence analysis, and taxonomic position of newly isolated fish iricloviruses. Virology 229:212-220

Miyata M, Matsuno K, Jung SJ, Danayadol Y, Miyazaki T (1997) Genetic similarity of iridoviruses from Japan and Thailand. J Fish Dis 20:127-134

Plumb JA, Grizzle JM, Young HE, Noyes AD (1996) An iridovirus isolated from wild largemouth bass. J Aquat Anim Health 8:265-270

Pozet R, Morand M, Moussa A, Torhy C, de Kinkelin P (1992) Isolation and preliminary characterization of a pathogenic icosahedral deoxyribovirus from the catfish lctalurus melas. Dis Aquat Org 14:35-42

Whittington RJ, Reddacliff GL (1995) Influence of environmental temperature on experimental infection of redfin perch (Perca fluviatilis) and rainbow trout (Oncorhynchus mykiss) with epizootic haematopoietic necrosis virus, an Australian iridovirus. Aust Vet J 72:421-424

Wolf K (1988) Fish viruses and fish viral diseases. Cornell University Press, lthaca, NY

Submitted: September 19, 1997; Accepted: January 7, 1998 Proofs received from author(s): March 2, 1998 